\title{
KETIDAKSEIMBANGAN HAK DAN KEWAJIBAN ANTARA INVESTOR ASING DENGAN PEKERJA INDONESIA DALAM PENGATURAN PENANAMAN MODAL DAN KETENAGAKERJAAN*
}

\author{
Sulistiowati** $^{* *}$ \\ Bagian Hukum Dagang, Fakultas Hukum Universitas Gadjah Mada, Yogyakarta \\ Jalan Sosio Yustisia Nomor 1 Bulaksumur, Sleman, D.I. Yogyakarta 55281
}

\begin{abstract}
This research purports to identify and find the form of imparity on the rights and obligations of the foreign investors and Indonesian workers in Indonesian regulations of investment law. The imparity is shown in: (i) discrepancies in minimum wage among employee working in foreign investment and domestic investment; (ii) rights and obligations; as well as (iii) legal culture which perceives Indonesian employee as one of the production factors. Such imparity, however, are not without purpose. It is aimed to complete vertical harmonization to avoid overlapping regulations. Nonetheless, the author finds this imparity still bring more favour to the foreign investors.
\end{abstract}

Keywords: imparity, rights and obligations, foreign investor, worker.

\section{Intisari}

Penelitian ini ditujukan untuk mengidentifikasi dan menemukan bentuk-bentuk ketidakseimbangan hak dan kewajiban antara penanam modal asing dan pekerja Indonesia dalam peraturan perundang-undangan mengenai penanaman modal. Ketidakseimbangan tampak pada: (i) upah minimum yang sama terhadap pekerja Indonesia baik yang bekerja di PMA maupun PMDN; (ii) hak dan kewajiban; serta (iii) budaya hukum yang menganggap pekerja Indonesia sebagai salah satu faktor produksi yang sama halnya dengan faktor produksi lainnya. Ketidakseimbangan ini bukanlah tanpa tujuan. Ketidakseimbangan yang ada ditujukan untuk menciptakan harmonisasi vertikal dalam rangka menghindari kebijakan yang tumpang tindih. Hanya saja, penulis berpendapat bahwa ketidakseimbangan ini masih lebih menguntungkan penanam modal asing.

Kata Kunci: ketidakseimbangan, hak dan kewajiban, penanam modal asing, pekerja.

\section{Pokok Muatan}

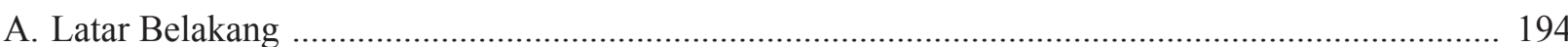

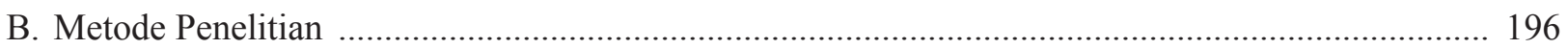

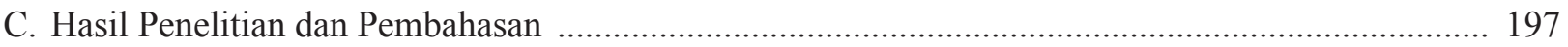

1. Wujud Ketidakseimbangan antara Investor Asing dan Pekerja Indonesia dalam Peraturan Perundang-undangan Penanaman Modal

2. Ketidakseimbangan dari Segi Pengupahan bagi Pekerja Indonesia yang Bekerja di Perusahaan

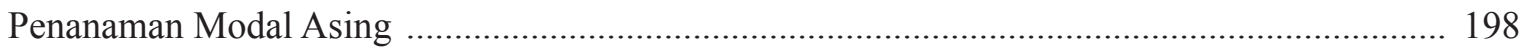

3. Hak dan Kewajiban Investor Asing dan Pekerja Indonesia ....................................................... 198

4. Ketidakseimbangan antara Investor Asing dan Pekerja Indonesia dari Segi Hukum sebagai

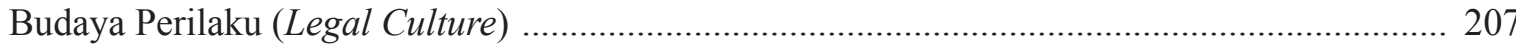

5. Penyebab Ketidakseimbangan Hak dan Kewajiban antara Investor Asing dan Pekerja Indonesia dalam Peraturan Perundang-undangan Penanaman Modal ........................................ 208

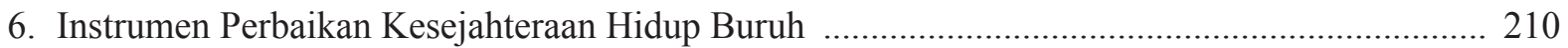

7. Kecenderungan Pemerintah ....................................................................................... 210

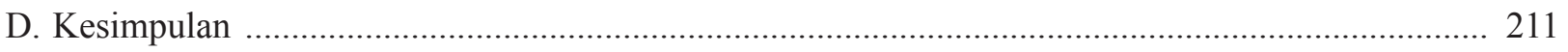

Hibah penelitian dari Unit Penelitian dan Pengabdian pada Masyarakat, Fakultas Hukum UGM, Tahun 2014.

Alamat korespondensi: sulistyowatiugm@yahoo.co.id 


\section{A. Latar Belakang}

Entitas bisnis didirikan dengan tujuan meningkatkan nilai aset pemegang saham secara maksimal. ${ }^{1}$ Suatu saat, seorang investor mungkin merasa bahwa kondisi bisnis di dalam negeri sudah tidak cukup mampu untuk membantunya meningkatkan nilai aset bisnisnya. Untuk itu investor dapat menanamkan modal di negara asing untuk mengembangkan bisnisnya. Prospek pengembangan bisnis di negara asing yang menawarkan daya tarik ongkos produksi yang lebih rendah akhirnya akan dilirik karena dianggap dapat menciptakan nilai jual output barang produksi yang lebih kompetitif di pasar. ${ }^{2}$

Indonesia juga memerlukan investasi asing untuk menumbuhkan perekonomian nasional. Kebutuhan akan investasi asing menuntut para pemangku kepentingan untuk menciptakan iklim investasi yang "nyaman" bagi investor asing. Iklim ini dapat diciptakan dengan cara meningkatkan unsur-unsur keunggulan komparatif maupun keunggulan kompetitif Indonesia; menerbitkan peraturan perundang-undangan penanaman modal asing yang dapat diterima semua pihak dan berlaku secara konsisten; dan dengan cara mengeluarkan kebijakan yang pada dasarnya dapat menguntungkan investor asing tanpa merugikan kepentingan nasional.

Pada 2 Maret 2006, Kementerian Koordinator Bidang Perekonomian menerbitkan suatu paket kebijakan yang mengandung 85 langkah strategis untuk memperbaiki iklim investasi. Paket ini dipayungi baju hukum berupa Instruksi Presiden Nomor 3 Tahun 2006 dan memiliki tujuan memacu pertumbuhan ekonomi di atas $6 \%$ pada tahun $2006 .{ }^{3}$
Paket kebijakan bidang ketenagakerjaan ini perlu didukung dengan iklim regulasi yang mampu mempertahankan fleksibilitas pasar kerja; menjamin terpenuhinya kondisi keseimbangan di mana upah pekerja bernilai setara dengan produktivitasnya; dan memberdayakan ekonomi yang berorientasi pada penciptaan lapangan kerja dan berorientasi pada pengusaha mikro, kecil, dan menengah. Untuk mencapai iklim regulasi yang demikian, dibutuhkan penciptaan lapangan pekerjaan di dalam negeri, peningkatan pertumbuhan ekonomi, penyerapan pengangguran ke pasar kerja, peningkatan arus masuk investasi asing, dan pencegahan keluarnya investasi asing.

Diharapkan kebijakan-kebijakan ketenagakerjaan ini dapat mewujudkan kesejahteraan rakyat sebagaimana diamanatkan dalam Pembukaan Undang-Undang Dasar Negara Republik Indonesia Tahun 1945 melalui pengurangan tingkat pengangguran, peningkatan penghasilan masyarakat, dan pengurangan kemiskinan. Dengan iklim penanaman modal yang baik perekonomian dapat tumbuh dan berkembang sehingga mampu melanjutkan pembangunan bidang-bidang lainnya, termasuk mengatasi permasalahan bangsa yang sangat mendasar, yaitu kebodohan, kemiskinan dan pengangguran.

Disinilah dapat dilihat terdapat irisan antara kepentingan investor asing dengan kepentingan pekerja Indonesia. Investor asing memiliki kepentingan melakukan kegiatan bisnis yang menguntungkan di Indonesia. Dalam paradigma kapitalisme, tenaga pekerja - terutama angkatan pekerja yang tidak terdidik dan terlatih — dianggap sebagai faktor produksi yang fleksibel. Sebagai

\footnotetext{
Mark J. Roe, 2001, The Shareholder Wealth Maximization Norm and Industrial Organization, Harvard Law School John M. Olin Center for Law, Economics and Business Discussion Paper Series, Cambridge, hlm. 339.

Sebagai entitas yang berorientasi pada laba, investor asing akan berusaha mencari komponen produksi yang paling rendah. Apalagi dalam konteks investasi asing, investor dihadapkan pada berbagai risiko investasi misalnya risiko politik, risiko nilai tukar mata uang, risiko penegakan hukum, dan lain sebagainya. Lihat dalam Hayakawa, Kimura, \& Lee, "How Does Country Risk Mather for Direct Investment?", dipresentasikan dalam Economic Research Institute for ASEAN and East Asia (ERIA), Jakarta, 2012.

Seperempat dari ke-85 langkah strategis itu berbentuk tindakan reformasi hukum bidang ketenagakerjaan, yakni menciptakan iklim hubungan industrial yang mendukung perluasan lapangan kerja; memperkuat perlindungan dan penempatan TKI di luar negeri; menyelesaikan berbagai perselisihan hubungan industrial secara cepat, murah dan berkeadilan; mempercepat proses penerbitan perizinan ketenagakerjaan; menciptakan pasar tenaga kerja yang fleksibel dan produktif; dan melakukan terobosan paradigma pembangunan transmigrasi dalam rangka perluasan lapangan kerja.
} 
akibatnya, investor cenderung ingin membayar pekerja dengan upah yang semurah-murahnya. Ketika faktor-faktor produksi tertentu (misalnya tarif dasar listrik atau tarif langganan air) menjadi mahal, upah pekerja biasanya menjadi salah satu faktor produksi pertama yang dipangkas. Di sisi lain, pekerja pasti ingin memperoleh upah yang setinggitingginya untuk memajukan kualitas hidupnya.

Sudah beberapa kali diberitakan di media massa betapa pengusaha dirugikan oleh kondisi aturan ketenagakerjaan di Indonesia terlalu proteksionis. Beberapa elemen dalam regulasi ketenagakerjaan yang dianggap berpotensi menghambat investasi adalah aturan PHK, perhitungan pesangon, penetapan upah, aturan mogok kerja, aturan alih daya (outsourcing), penggunaan tenaga kerja asing, aturan jaminan sosial, dan peradilan hubungan industrial.

Selain dari aspek regulasi, investor asing juga mengeluhkan sifat pekerja Indonesia yang dianggap sering melakukan demonstrasi, mudah mendirikan serikat pekerja sempalan, dan selalu menuntut kenaikan upah minimum (sebagaimana dilaporkan oleh Ernawati ${ }^{4}$ Galuh ${ }^{5}$; R. Lucky ${ }^{6}$; Yusuf ${ }^{7}$ ). Hernawan $^{8}$ juga melaporkan bahwa cara pekerja menyampaikan tuntutan dan aspirasinya dalam mogok kerja juga cenderung dilakukan dengan tindakan yang dapat menarik perhatian masyarakat luas, misalnya dengan merusak perusahaan atau dengan melakukan long march ke instansi-instansi pemerintah. Tidak dipungkiri aksi demonstrasi ini akan berdampak pada produktivitas pabrik dan pada akhirnya merugikan kepentingan pengusaha untuk merasa nyaman dalam melakukan kegiatan bisnis dan tidak terbebas dari aksi-aksi pekerja yang menghambat kegiatan ekonomi. Selain itu aksi mogok juga berpotensi mengganggu proses produksi dan sebagai akibatnya pesanan dari luar tersendat, seperti produk-produk sepatu, tekstil dan barang-barang elektronik.

Kebijakan dan peraturan perundangundangan suatu negara biasanya sudah cukup ampuh dalam membatasi nafsu investor meningkatkan aset mereka secara tak terkendali dan melindungi kepentingan pekerja. $^{9}$ Akan tetapi, atas nama pertumbuhan ekonomi, arah haluan kebijakan dan hukum suatu negara dapat pula membiarkan atau bahkan memberi insentif bagi investor asing untuk melakukan kegiatan ekonomi sebesar-besarnya tanpa memperhatikan kepentingan pekerja.

Hal ini terutama dapat terjadi pada negara-negara yang sedang berada dalam tahap industrialisasi. Mereka bersandar pada kelompokkelompok kontributif yang sumbangsihnya dalam mendorong kegiatan ekonomi negara besar. Kelompok-kelompok yang dianggap kurang kontributif dalam memajukan kegiatan ekonomi negara disisihkan dan dinomorduakan. Oleh karenanya, agaknya bukan merupakan pernyataan yang hiperbolis apabila disimpulkan bahwa negara industrialisasi cenderung lebih melindungi kepentingan pengusaha karena, bertolak belakang dengan pekerja, pengusaha adalah kelompok yang banyak memberikan sumbangan aktif kepada pertumbuhan ekonomi negara dan memiliki akses kepada sumber daya ekonomi dan politik. ${ }^{10}$ Dengan demikian, apabila terjadi konflik, maka besar kemungkinannya pemerintah akan berpihak kepada kepentingan pengusaha. Contoh keberpihakan pada kepentingan pengusaha ini misalnya adalah usulan mewujudkan keterbukaan pasar dengan menghapus serikat pekerja dan menyederhanakan proses

\footnotetext{
Dian Ernawati, "Buruh Kerjanya Demo Terus, Investor Kabur!", http://suarapengusaha.com/2013/01/13/buruh-kerjanya-demo-terusinvestor-kabur/, diakses 15 Maret 2015.

Iwan Galuh, "Pengusaha Menilai Buruh Sulit Diajak Dialog", http://suarapengusaha.com/2013/01/21/pengusaha-menilai-buruh-sulit-diajakdialog/, diakses 15 Maret 2015.

Lucky R., "Buruh Sepati Indonesia Punya Upah Lebih Besar Dibandingkan China dan Vietnam”, http://www.antaranews.com/berita/340950/ buruh-sepatu-indonesa-punya-upah-lebih-besar-dibandingkan-china-dan-vietnam, diakses 15 Maret 2015.

Hari Yusuf, "Buruh Batam Serukan Boikot Produk Samsung", http://suarapengusaha.com/2012/12/10/buruh-batam-serukan-boikot-produksamsung/, diakses 15 Maret 2015.

Ari Hernawan, "Hubungan Industrial dalam Perspektif Teori Keadilan John Rawls", Jurnal Mimbar Hukum, Vol. 26, No. 2, Juni 2014.

Roe, Mark J., Loc.cit.

Ari Hernawan, Loc.cit.
} 
penyelesaian sengketa hubungan industrial. ${ }^{11}$

Indonesia sendiri adalah negara yang sedang berada dalam tahap industrialisasi. Apabila dihadapkan dengan ancaman angkat kakinya pengusaha asing dari tanah air, wajar apabila pemerintah Indonesia cenderung untuk mengakomodasi kepentingan pengusaha sebagai pemilik kapital dan penggerak roda perekonomian terlebih dahulu sebelum mengakomodasi kepentingan pekerja.

Berdasarkan penjabaran latar belakang di atas, permasalahan yang akan diteliti adalah sebagai berikut: Pertama, bagaimana wujud ketidakseimbangan hak dan kewajiban investor asing dan pekerja Indonesia dalam peraturan perundang-undangan penanaman modal? Kedua, mengapa pengaturan hak dan kewajiban antara investor asing dan pekerja Indonesia dalam peraturan perundang-undangan penanaman modal tidak seimbang?

\section{B. Metode Penelitian}

Penelitian ini menggunakan pendekatan yuridis-empiris, yaitu penelitian yang didasarkan pada penelitian kepustakaan dan penelitian lapangan. Penelitian kepustakaan dilakukan untuk memperoleh data sekunder di bidang hukum agar peneliti dapat menggali dan mengkaji secara mendalam data-data yang berkaitan dengan permasalahan yang diteliti. Penelitian lapangan dilakukan untuk mengetahui sifat, keadaan, atau gejala dari obyek penelitian. Dalam penelitian kepustakaan, peneliti akan mengacu kepada bahan hukum primer, bahan hukum sekunder, dan bahan hukum tersier. Bahan hukum primer adalah bahan hukum yang mengikat, baik ketentuan hukum nasional dan internasional yang berkenaan dengan permasalahan hukum di dalam penelitian ini, yang meliputi Undang-Undang Nomor 25 Tahun 2007 tentang Penanaman Modal dan Peraturan Presiden Nomor 36 Tahun 2010.
Sedangkan bahan hukum sekunder adalah bahanhukum yangmemberikan penjelasanmengenai bahan hukum primer, yang meliputi buku-buku yang berkaitan dengan permasalahan yang diajukan dalam penelitian ini; dan hasil seminar, makalah, artikel yang berkaitan dengan permasalahan yang diajukan dalam penelitian. Bilamana diperlukan, penelitian ini juga akan menggunakan bahan hukum tersier, yakni bahan hukum yang memberikan penjelasan mengenai bahan hukum primer dan sekunder, yang meliputi kamus hukum dan kamus bahasa Indonesia. Dalam hal penelitian lapangan dilaksanakan di wilayah DKI Jakarta dengan pertimbangan BKPM dan kementeriankementerian terkait dengan kewenangan regulasi ketenagakerjaan, perekonomian, dan investasi asing berada di Jakarta. Subyek penelitian ini adalah nara sumber yang berasal dari instansi pemerintah seperti BKPM dan Kementerian Transmigrasi dan Tenaga Kerja. Selain itu, narasumber lain dalam penelitian ini adalah praktisi dan akademisi yang mengetahui dan memahami hubungan antara hukum investasi dan hukum ketenagakerjaan.

Teknik pengumpulan data dilakukan dengan wawancara dan focus group discussion. Alat pengumpulan data dalam penelitian ini adalah studi dokumen dan pedoman wawancara. Pedoman disusun sebagai panduan untuk memperoleh data dari responden maupun narasumber. Analisis data berisi uraian mengenai cara-cara analisis, yaitu bagaimana memanfaatkan yang merupakan penjelasan mengenai proses memanfaatkan data yang terkumpul untuk selanjutnya digunakan dalam menyelesaikan masalah penelitian. Dengan kata lain, analisis data merupakan penjelasan proses memanfaatkan data yang terkumpul untuk selanjutnya digunakan dalam menyelesaikan masalah penelitian. ${ }^{12}$

Metode pengolahan data yang digunakan adalah dengan mengumpulkan data yang diperoleh dari penelitian kepustakaan, peraturan-perundang-

Business Line, "Reform Labour Laws for FDI", http://www.hindu.com/businessline/2001/08/11/stories/01112003.htm, diakses 20 Maret 2015. Maria S. W. Sumardjono, 2001, Pedoman Pembuatan Usulan Penelitian: Sebuah Panduan Dasar, Gramedia Pustaka Utama, Jakarta, hlm. 38. 
undangan, buku-buku dan artikel-artikel, yang diolah serta dianalisis dengan menggunakan metode kualitatif. Data yang diperoleh dari penelitian kemudian dipisahkan antara data yang relevan dengan yang tidak relevan. Data yang relevan dikaitkan dengan judul, latar belakang masalah dan rumusan masalah. Metode kualitatif merupakan tata cara penelitian yang menghasilkan data deskriptif analitis, yaitu keterangan yang disampaikan oleh responden secara tertulis atau lisan, dan juga perilaku nyata, diteliti dan dipelajari sebagai sesuatu yang utuh. ${ }^{13}$

\section{Hasil Penelitian dan Pembahasan}

1. Wujud Ketidakseimbangan antara Investor Asing dan Pekerja Indonesia dalam Peraturan Perundang-undangan Penanaman Modal

Keseimbangan sebagai suatu konsep yang ideal mengusahakan keselarasan agar tidak ada pihak yang mendominasi ataupun menguasai pihak lainnya. ${ }^{14}$ Penerapan konsep keseimbangan ke dalam suatu peraturan perundang-undangan merupakan salah satu tantangan tersendiri bagi badan legislatif. Terlebih ketika subjek pengaturan merupakan pihak yang memiliki kepentingan ekonomi yang saling berseberangan. Dari satu sisi, Indonesia sebagai negara berkembang ingin menstimulasi peran investor asing untuk menanamkan modalnya di dalam negeri. Namun, dalam waktu yang bersamaan, pemerintah Indonesia juga diharapkan untuk melindungi hak-hak tenaga kerja.

Investor asing yang memiliki tujuan untuk menciptakan keuntungan cenderung menekan biaya produksi dengan cara menanamkan modal di negara yang memiliki ketersediaan bahan baku dengan harga rendah serta menerapkan standar rendah terhadap pemenuhan hak-hak pekerja. ${ }^{15}$ Sementara itu, tenaga kerja menginginkan pemenuhan hak untuk mencukupi kebutuhan dasar mereka. Dua kepentingan yang berbeda menempatkan pemerintah sebagai pembuat kebijakan untuk berhati-hati dalam mengatur hak dan kewajiban kedua belah pihak. Ancaman pekerja melakukan mogok kerja, serta investor asing akan hengkang, merelokasi, atau membatalkan rencana investasinya di Indonesia ${ }^{16}$ senantiasa membayang-bayangi pemerintah dalam setiap penyusunan kebijakan serta peraturan perundang-undangan.

Meskipun konsep keseimbangan telah diusahakan oleh pemerintah, namun keadaan yang seimbang, sama rata, dinilai sebagai suatu konsep yang utopis. Terutama ketika investor asing dipandang memiliki posisi tawar (bargaining position) yang lebih tinggi daripada para pekerja sehingga pemerintah memiliki kecenderungan tertentu untuk menciptakan iklim penanaman modal yang baik bagi para investor asing. Hanya saja, pemerintah juga perlu memperhatikan fakta bahwa sektor tenaga kerja sendiri memiliki peran yang penting dalam investasi ${ }^{17}$ karena tenaga kerja dianggap sebagai salah satu faktor yang mempengaruhi pembentukan nilai barang dan jasa. ${ }^{18}$ Pemerintah telah berusaha menciptakan peraturan perundang-undangan yang seimbang bagi investor asing dan para pekerja, namun peneliti menilai ada beberapa ketidakseimbangan yang dapat dicermati, antara lain: (a) ketidakseimbangan secara porsi pengaturan; (b) ketidakseimbangan antara hak dan kewajiban investor asing dan pekerja dalam peraturan perundang-undangan terkait penanaman modal di Indonesia; serta (c) ketidakseimbangan hukum sebagai budaya perilaku.

\footnotetext{
Soerjono Soekanto, 1986, Pengantar Penelitian Hukum, UI Press, Jakarta, hlm. 250.

Herlien Budiono, 2006, Asas Keseimbangan bagi Hukum Perjanjian Indonesia, Hukum Perjanjian Berlandaskan Asas-Asas Wigati Indonesia, Citra Aditya Bakti, Bandung, hlm. 304.

15 Will Martin, Keith E. Maskus, "Core Labour Standards and Competitiveness: Implications for Global Trade Policy", Review of International Economics, 2001, hlm. 317-328.

16 James Castle, "Hengkangnya Investor Asing dari Indonesia", Kompas, 29 November 2013.

17 Suparji, 2008, Penanaman Modal Asing di Indonesia: Insentif v. Pembatasan, Universitas Al-Azhar Indonesia Fakultas Hukum, Jakarta.

18 Rahardjo M. Dawam, "Peranan Pekerja dalam Pembangunan Ekonomi”, Jurnal Reformasi Ekonomi, Vol. 4, No. 1, Januari-Desember 2003, hlm. 51 .
} 
2. Ketidakseimbangan dari Segi Pengupahan bagi Pekerja Indonesia yang Bekerja di Perusahaan Penanam Modal Asing

Upah minimum adalah upah bulanan terendah yang terdiri atas upah pokok termasuk tunjangan tetap yang ditetapkan oleh gubernur sebagai jaring pengaman. ${ }^{19}$ Upah minimum ini kemudian dibagi menjadi Upah Minimum Provinsi (UMP) serta Upah Minimum Kabupaten/Kota (UMK). ${ }^{20}$ Dari segi sektor lapangan usaha, pemerintah juga menetapkan adanya Upah Minimum Sektoral Provinsi (UMSP) dan Upah Minimum Sektoral Kabupaten/Kota (UMSK). ${ }^{21}$ Upah minimum sektoral dibagi berdasarkan lapangan usaha menurut Klasifikasi Baku Lapangan usaha Indonesia (KBLI). ${ }^{22}$

Sebelum menetapkan upah minimum, Dewan Pengupahan Provinsi atau Dewan Pengupahan Kabupaten/Kota diwajibkan untuk melakukan penelitian dan menghimpun data mengenai perusahaan yang berada dalam wilayah hukumnya. ${ }^{23}$ Dewan Pengupahan Kabupaten/Kota melaporkan temuannya kepada bupati/walikota, untuk selanjutnya dipertimbangkan menjadi rekomendasi yang berasal dari masing-masing kota/kabupaten. Sementara itu, Dewan Pengupahan Provinsi, melalui Satuan Kerja Perangkat Daerah Provinsi menyampaikan hasil penelitian kepada gubernur. $^{24}$

Penetapan upah minimum ini ditujukan untuk melindungi upah pekerja agar tidak merosot pada tingkat yang paling rendah sebagai akibat dari ketidakseimbangan pasar kerja. Pemerintah menilai perlu adanya penyelarasan kebijakan upah minimum dengan memperhatikan produktivitas dan pertumbuhan ekonomi guna mewujudkan keberlangsungan usaha dan peningkatan kesejah- teraan pekerja. ${ }^{25}$ Pengusahaan kesejahteraan bagi kaum pekerja tampak pada tujuan penetapan upah minimum, yaitu untuk memenuhi Kebutuhan Hidup Layak (KHL). ${ }^{26}$

Selain mekanisme penetapan upah minimum, pemerintah juga membuka kesempatan bagi pengusaha dan pekerja atau serikat pekerja/buruh untuk menetapkan sendiri upah berdasarkan kesepakatan. Kesepakatan yang dicapai antara kedua belah pihak tetap harus menaati peraturan perundang-undangan yang ada. Salah satunya adalah ketentuan mengenai besarnya kesepakatan upah yang tidak boleh lebih rendah dari ketentuan upah minimum. ${ }^{27}$

Sejauh ini tidak ada pembedaan pengaturan yang diberikan mengenai upah minimum pekerja yang harus diberikan oleh perusahaan penanam modal nasional dan asing. Penulis beranggapan bahwa upah minimum seharusnya hanya berlaku bagi pekerja yang bekerja di perusahaan Penanam Modal Dalam Negeri (PMDN). Perusahaan modal asing pada dasarnya menuntut pekerjanya untuk memiliki kemampuan yang lebih tinggi dan memberikan beban kerja yang lebih besar. Oleh karena itu, sudah selayaknya pekerja Indonesia yang bekerja di perusahaan PMA diberikan upah minimum yang lebih tinggi dibandingkan dengan pekerja Indonesia yang bekerja di perusahaan PMDN.

\section{Hak dan Kewajiban Investor Asing dan Pekerja Indonesia}

Dalam UU Penanaman Modal, terdapat ketidakseimbangan antara hak dan kewajiban investor asing dengan pekerja Indonesia. Pada pengaturannya, terdapat beberapa hak pekerja Indonesia yang harus dipenuhi oleh investor asing.

\footnotetext{
Pasal 1 ayat (1) Peraturan Menteri Tenaga Kerja dan Transmigrasi Nomor 7 Tahun 2013 tentang Upah Minimum. Pasal 2 huruf a Peraturan Menteri Tenaga Kerja dan Transmigrasi Nomor 7 Tahun 2013 tentang Upah Minimum. Pasal 2 huruf b Peraturan Menteri Tenaga Kerja dan Transmigrasi Nomor 7 Tahun 2013 tentang Upah Minimum. Pasal 1 ayat (6) Peraturan Menteri Tenaga Kerja dan Transmigrasi Nomor 7 Tahun 2013 tentang Upah Minimum. Pasal 13 ayat (1) Peraturan Menteri Tenaga Kerja dan Transmigrasi Nomor 7 Tahun 2013 tentang Upah Minimum. Pasal 12 Peraturan Menteri Tenaga Kerja dan Transmigrasi Nomor 7 Tahun 2013 tentang Upah Minimum.

Pertimbangan huruf a Peraturan Menteri Tenaga Kerja dan Transmigrasi Nomor 7 Tahun 2013 tentang Upah Minimum. Pasal 3 ayat (1) Peraturan Menteri Tenaga Kerja dan Transmigrasi Nomor 7 Tahun 2013 tentang Upah Minimum.

Pasal 91 ayat (1) Undang-Undang Nomor 13 Tahun 2003 tentang Ketenagakerjaan (Lembaran Negara Republik Indonesia Tahun 2003 Nomor 39, Tambahan Lembaran Negara Republik Indonesia Nomor 4279).
} 
Namun, tidak diatur kewajiban yang harus dipenuhi oleh pekerja Indonesia yang harus dilaksanakan dalam bekerja pada perusahaan penanaman modal asing. Lebih lanjut, peneliti akan menganalisa apakah hak yang dimiliki oleh pekerja Indonesia telah menunjukkan keseimbangan pengaturan antara kepentingan investor asing dan pekerja itu sendiri. Hak tersebut tercantum dalam peraturan perundang-undangan mengenai Penanaman Modal serta Ketenagakerjaan.

\section{a. Perusahaan Penanaman Modal da- lam Memenuhi Kebutuhan Tenaga Kerja Harus Mengutamakan Tenaga Kerja Warga Negara Indonesia ${ }^{28}$}

Penanaman modal asing di Indonesia ditujukan untuk mempercepat pembangunan ekonomi nasional. Untuk mencapai tujuan tersebut, pemerintah tidak hanya memerlukan suntikan dana dari para investor, tetapi juga ketersediaan lapangan kerja bagi warga negara Indonesia. ${ }^{29}$ Sebagai salah satu bentuk insentif, pemerintah memberikan fasilitas penanaman modal berupa berbagai macam kemudahan bagi para investor yang usahanya menyerap banyak tenaga kerja. ${ }^{30}$

Indonesia, dengan jumlah penduduk kurang lebih 237 juta jiwa ${ }^{31}$ membutuhkan lapangan kerja bagi para penduduknya. Data dari Badan Pusat Statistik menyebutkan bahwa pada tahun 2004 hingga 2013, angka minimum pengangguran di Indonesia berjumlah sekitar 7.170.000 (tujuh juta seratus tujuh puluh ribu juta) orang atau 5,92\% dari keseluruhan angkatan kerja yang ada. $^{32}$

Jumlah penduduk yang semakin bertambah dinilai tidak sebanding dengan kemampuan pemerintah untuk memberikan lapangan kerja bagi warga negaranya. ${ }^{33}$ Oleh karena itu, pemerintah mewajibkan investor asing untuk memprioritaskan tenaga kerja warga negara Indonesia. Pengutamaan tenaga kerja Warga Negara Indonesia (WNI) juga diimbangi dengan pembatasan tenaga kerja Warga Negara Asing (WNA) yang bekerja dalam wilayah Indonesia. Lapangan kerja yang ada harus mengutamakan tenaga kerja Indonesia pada semua jenis jabatan, ${ }^{34}$ jika belum ada tenaga kerja Indonesia yang dianggap mampu untuk melakukan pekerjaan tersebut, maka jabatan tersebut dapat diduduki oleh tenaga kerja asing. ${ }^{35}$ Selain itu, pemerintah juga mengharuskan perusahaan penanaman modal untuk memiliki izin penggunaan tenaga kerja warga negara asing. ${ }^{36}$ Pembatasan ini dimaksudkan agar penggunaan tenaga kerja warga negara asing dilaksanakan secara selektif dalam rangka pendayagunaan tenaga kerja Indonesia. ${ }^{37}$

Memprioritaskan tenaga kerja warga negara Indonesia tidak hanya memberikan keuntungan bagi negara, tetapi juga bagi

Pasal 10 ayat (1) Undang-Undang Nomor 25 Tahun 2007 tentang Penanaman Modal (Lembaran Negara Republik Indonesia Tahun 2007 Nomor 67, Tambahan Lembaran Negara Republik Indonesia Nomor 4724).

$29 \quad$ Pasal 3 ayat (2) huruf b Undang-Undang Nomor 25 Tahun 2007 tentang Penanaman Modal (Lembaran Negara Republik Indonesia Tahun 2007 Nomor 67, Tambahan Lembaran Negara Republik Indonesia Nomor 4724).

30 Pasal 18 ayat (3) huruf a Undang-Undang Nomor 25 Tahun 2007 tentang Penanaman Modal (Lembaran Negara Republik Indonesia Tahun 2007 Nomor 67, Tambahan Lembaran Negara Republik Indonesia Nomor 4724).

31 Berdasarkan sensus penduduk tahun 2010 yang dilakukan oleh Badan Pusat Statistik, "Sensus Penduduk Tahun 2010", http://www.bps.go.id/ tab sub/view.php?tabel=1\&id subyek=12, diakses 31 Agustus 2014.

32 Badan Pusat Statistik, "Jumlah Angkatan Kerja, Penduduk Bekerja, Pengangguran, TPAK dan TPT", http://www.bps.go.id/tab_sub/view. php? kat $=1 \&$ tabel $=1 \&$ daftar $=1 \&$ id subyek $=06 \&$ notab $=5$, diakses 31 Agustus 2014 .

33 Ahmad Erani Yustika, "Investasi dan Penanaman Modal", Bisnis Indonesia, 24 September 2008.

34 Pasal 4 ayat (1) Peraturan Presiden Nomor 72 Tahun 2014 tentang Penggunaan Tenaga Kerja Asing serta Pelaksanaan Pendidikan dan Pelatihan Tenaga Kerja Pendamping.

35 Pasal 4 ayat (2) Peraturan Presiden Nomor 72 Tahun 2014 tentang Penggunaan Tenaga Kerja Asing serta Pelaksanaan Pendidikan dan Pelatihan Tenaga Kerja Pendamping.

36 Pasal 42 Undang-Undang Nomor 13 Tahun 2003 tentang Ketenagakerjaan (Lembaran Negara Republik Indonesia Tahun 2003 Nomor 39 , Tambahan Lembaran Negara Republik Indonesia Nomor 4279).

37 Penjelasan Pasal 42 ayat (1) Undang-Undang Nomor 13 Tahun 2003 tentang Ketenagakerjaan (Lembaran Negara Republik Indonesia Tahun 2003 Nomor 39, Tambahan Lembaran Negara Republik Indonesia Nomor 4279). 
investor asing itu sendiri. Jika dibandingkan dengan negara di Asia Tenggara yang lain, upah minimum pekerja (UMP) di Indonesia relatif rendah. Pada tahun 2013, UMP bagi pekerja di Jakarta berkisar di angka USD 226.5 per bulan. Sebagai perbandingan, Malaysia menetapkan UMP sebesar USD 296 bagi para pekerjanya. Sementara itu, Thailand memberikan standar minimum upah sebesar USD 310.2. ${ }^{38}$ Tidak dapat dipungkiri bahwa upah pekerja merupakan salah satu faktor yang menentukan besar biaya yang harus dikeluarkan oleh perusahaan. Dengan memprioritaskan pekerja Indonesia investor asing mampu mengoptimalkan biaya produksi sehingga dapat meningkatkan persaingan di bidang usahanya masing-masing.

\section{b. Perusahaan Penanaman Modal Wajib Meningkatkan Kompetensi Tenaga Kerja Warga Negara Indonesia melalui Pelatihan Kerja Sesuai dengan Ketentuan Peraturan Perundang-Undangan ${ }^{39}$}

Peningkatan kompetensi tenaga kerja warga negara Indonesia merupakan salah satu kewajiban yang harus dilakukan oleh investor asing untuk meningkatkan kualitas sumber daya manusia di Indonesia. Kewajiban ini ditegaskan kembali dalam Peraturan Kepala Badan Koordinasi Penanaman Modal (BKPM) Nomor 3 Tahun 2012 tentang Pedoman dan Tata Cara Pengendalian Pelaksanaan Penanaman Modal yang berbunyi, "Setiap penanam modal berkewajiban meningkatkan kompetensi tenaga kerja warga negara Indonesia melalui pelatihan kerja sesuai dengan ketentuan peraturan perundang-undangan". ${ }^{40}$ Untuk memantau perkembangan pelaksanaan pelatihan kerja terhadap warga negara Indonesia, perusahaan penanaman modal diwajibkan untuk menyerahkan Laporan Kegiatan Penanaman Modal (LKPM) secara berkala. ${ }^{41}$ Dalam tahap konstruksi (pembangunan), perusahaan penanaman modal diwajibkan untuk menyerahkan LKPM setiap tiga bulan, sementara jika perusahaan sudah beroperasi, maka LKPM diserahkan setiap enam bulan. ${ }^{42}$

Dalam laporan yang disusun oleh perusahaan penanam modal, investor diwajibkan untuk melaporkan jumlah tenaga kerja yang digunakan dalam perusahaan tersebut. Dalam laporan ini, investor diwajibkan untuk menyebutkan jumlah tenaga kerja Warga Negara Indonesia dengan tenaga kerja asing. ${ }^{43}$ Selain itu, investor juga wajib melaporkan kewajiban perusahaan yang telah dijalankan dalam kurun waktu tertentu. Salah satu kewajiban yang harus dilaporkan yaitu mengenai pelatihan tenaga kerja Indonesia. Laporan ini harus mencantumkan jenis pelatihan yang diberikan, pelaksana pelatihan, serta jumlah tenaga kerja warga negara Indonesia yang dilatih. ${ }^{44}$

Kewajiban untuk melaporkan pelatihan tenaga kerja Indonesia diberlakukan bagi perusahaan yang mempekerjakan tenaga

38 ASEAN Briefing, "Minimum Wage Levels Across ASEAN", http://www.aseanbriefing.com/news/2013/04/16/minimum-wage-levels-acrossasean.html, diakses 31 Agustus 2014.

39 Pasal 10 ayat (3) Undang-Undang Nomor 25 Tahun 2007 tentang Penanaman Modal (Lembaran Negara Republik Indonesia Tahun 2007 Nomor 67, Tambahan Lembaran Negara Republik Indonesia Nomor 4724).

40 Pasal 5 huruf a Peraturan Kepala Badan Koordinasi Penanaman Modal Nomor 3 Tahun 2012 tentang Pedoman dan Tata Cara Pengendalian Pelaksanaan Penanaman Modal.

41 Pasal 11 ayat (1) Peraturan Kepala Badan Koordinasi Penanaman Modal Nomor 3 Tahun 2012 tentang Pedoman dan Tata Cara Pengendalian Pelaksanaan Penanaman Modal.

42 Pasal 11 ayat (2) Peraturan Kepala Badan Koordinasi Penanaman Modal Nomor 3 Tahun 2012 tentang Pedoman dan Tata Cara Pengendalian Pelaksanaan Penanaman Modal.

43 Lampiran II, Bagian III Penggunaan Tenaga Kerja Peraturan Kepala Badan Koordinasi Penanaman Modal Nomor 3 Tahun 2012 tentang Pedoman dan Tata Cara Pengendalian Pelaksanaan Penanaman Modal.

44 Lampiran II, Bagian VI Kewajiban Perusahaan Peraturan Kepala Badan Koordinasi Penanaman Modal Nomor 3 Tahun 2012 tentang Pedoman dan Tata Cara Pengendalian Pelaksanaan Penanaman Modal. 
kerja asing. Perusahaan tersebut memiliki kewajiban untuk memberikan kompensasi ${ }^{45}$ terhadap tenaga kerja Indonesia karena telah mempekerjakan tenaga kerja asing yang mengambil porsi kesempatan kerja yang dimiliki oleh tenaga kerja Indonesia. ${ }^{46}$ Kewajiban pemberian kompensasi tersebut diatur dalam Peraturan Menteri Tenaga Kerja dan Transmigrasi Nomor 12 Tahun 2013 tentang Tata Cara Penggunaan Tenaga Kerja Asing. Kompensasi diartikan sebagai dana yang harus dibayar oleh pemberi kerja TKA kepada negara atas penggunaan TKA. ${ }^{47}$ Peraturan ini menentukan besarnya dana kompensasi yang harus dibayarkan yaitu sebesar USD 100 (seratus dolar Amerika) per jabatan per bulan untuk setiap TKA yang dipekerjakan di Indonesia. ${ }^{48}$

Pemberian pelatihan terhadap tenaga kerja warga negara Indonesia juga diatur dalam Peraturan Presiden Nomor 72 Tahun 2014 tentang Penggunaan Tenaga Kerja Asing serta Pelaksanaan Pendidikan dan Pelatihan Tenaga Kerja Pendamping. Pendidikan dan pelatihan yang diberikan kepada tenaga kerja Indonesia harus disesuaikan dengan kualifikasi jabatan yang diduduki oleh TKA. ${ }^{49}$ Pelatihan ini dimaksudkan untuk memberikan bekal pengetahuan yang cukup bagi tenaga kerja Indonesia sehingga mampu melakukan tugas dan kewajibannya dengan baik ketika diberi kepercayaan untuk mengisi jabatan yang sama atau setara dengan yang sedang dijabat oleh TKA pada saat ini.

\section{c. Perusahaan Penanaman Modal yang Mempekerjakan Tenaga Kerja Asing Diwajibkan Menyelenggarakan Pe- latihan dan Melakukan Alih Tek- nologi kepada Tenaga Kerja Warga Negara Indonesia ${ }^{50}$}

Pada dasarnya, kesempatan kerja diberikan terlebih dahulu kepada pekerja Indonesia, ${ }^{51}$ hanya saja jika belum ada pekerja Indonesia yang memiliki kompetensi memadai untuk mengisi jabatan tersebut, kesempatan akan diberikan kepada TKA dengan berbagai macam kewajiban yang harus dipenuhi oleh perusahaan penanam modal asing.

Salah satu kewajiban yang harus dilakukan oleh investor asing yang mempekerjakan TKA adalah menunjuk pekerja Indonesia untuk menjadi pendamping $^{52}$ serta mengadakan pendidikan dan pelatihan sesuai dengan kualifikasi jabatan yang diduduki TKA. ${ }^{53}$ Pendidikan dan pelatihan tersebut memiliki tujuan utama untuk melaksanakan alih teknologi dan alih keahlian dari TKA terhadap pekerja Indonesia. ${ }^{54}$ Dengan adanya alih pengetahuan, diharapkan pekerja Indonesia mampu memiliki kompetensi dapat digunakan untuk mengisi jabatan yang saat ini masih diduduki oleh TKA. ${ }^{55}$ Dalam pelatihan ini, pekerja

45 Pasal 47 Undang-Undang Nomor 13 Tahun 2003 tentang Ketenagakerjaan (Lembaran Negara Republik Indonesia Tahun 2003 Nomor 39 , Tambahan Lembaran Negara Republik Indonesia Nomor 4279).

46 Wawancara dengan Bapak Budiman, S.H.

47 Pasal 1 ayat (6) Peraturan Menteri Tenaga Kerja dan Transmigrasi Nomor 12 Tahun 2013 tentang Tata Cara Penggunaan Tenaga Kerja Asing. 4 Pasal 32 ayat (1) Peraturan Menteri Tenaga Kerja dan Transmigrasi Nomor 12 Tahun 2013 tentang Tata Cara Penggunaan Tenaga Kerja Asing.

49 Pasal 11 Peraturan Presiden Nomor 72 Tahun 2014 tentang Penggunaan Tenaga Kerja Asing serta Pelaksanaan Pendidikan dan Pelatihan Tenaga Kerja Pendamping.

50 Pasal 10 ayat (4) Undang-Undang Nomor 25 Tahun 2007 tentang Penanaman Modal (Lembaran Negara Republik Indonesia Tahun 2007 Nomor 67, Tambahan Lembraan Negara Republik Indonesia Nomor 4724).

51 Pasal 4 ayat (1) Peraturan Presiden Nomor 72 Tahun 2014 tentang Penggunaan Tenaga Kerja Asing serta Pelaksanaan Pendidikan dan Pelatihan Tenaga Kerja Pendamping.

52 Pasal 11 ayat (1) huruf a Peraturan Presiden Nomor 72 Tahun 2014 tentang Penggunaan Tenaga Kerja Asing serta Pelaksanaan Pendidikan dan Pelatihan Tenaga Kerja Pendamping.

53 Pasal 11 ayat (1) huruf b Peraturan Presiden Nomor 72 Tahun 2014 tentang Penggunaan Tenaga Kerja Asing serta Pelaksanaan Pendidikan dan Pelatihan Tenaga Kerja Pendamping.

54 Pasal 12 Peraturan Presiden Nomor 72 Tahun 2014 tentang Penggunaan Tenaga Kerja Asing serta Pelaksanaan Pendidikan dan Pelatihan Tenaga Kerja Pendamping.

55 Penjelasan Pasal 45 ayat (1) huruf a Undang-Undang Nomor 13 Tahun 2003 tentang Ketenagakerjaan (Lembaran Negara Republik Indonesia Tahun 2003 Nomor 39, Tambahan Lembaran Negara Republik Indonesia Nomor 4279). 
Indonesia berhak mendapatkan sertifikat sebagai bukti peningkatan keahlian yang telah ia tempuh. ${ }^{56}$

Tidak dapat dipungkiri bahwa alih teknologi memiliki peran penting dalam peningkatan kemampuan serta kualitas SDM di Indonesia, dalam konteks ini, khususnya pekerja Indonesia. Mansfield mengemukakan alih teknologi merupakan salah satu proses penting yang dapat mempengaruhi performa ekonomi sebuah badan usaha maupun negara. ${ }^{57}$ Dijabarkan lebih lanjut bahwa alih teknologi merupakan jantung dari pertumbuhan ekonomi, sehingga kemajuan suatu bidang usaha sangat berkaitan erat dengan efektivitas dari alih teknologi itu sendiri..$^{58}$

Investor asing yang ingin menempatkan TKA dalam perusahaannya memiliki kewajiban untuk menunjuk pekerja Indonesia sebagai pendamping. Di sisi lain, investor juga memiliki hak untuk mendapatkan tenaga kerja pendamping yang memiliki keahlian dan latar belakang pendidikan yang sesuai dengan jabatan yang akan diberikan kepada TKA. ${ }^{59}$ Persyaratan ini merupakan salah satu bentuk keseimbangan yang diberikan oleh peraturan perundang-undangan terhadap investor asing. Perusahaan penanaman modal asing memiliki hak untuk memilih pekerja yang berkompeten untuk jabatan yang akan diduduki oleh TKA.

Pekerja Indonesia diberi hak untuk mendampingi TKA pada suatu jabatan tertentu. Para pekerja juga diberi kewajiban untuk mengikuti pelatihan serta pendidikan yang diberikan oleh perusahaan, baik secara langsung maupun tidak langsung (melalui pelatihan eksternal). Kewajiban ini harus dijalankan dengan baik sehingga tujuan dari alih teknologi seperti yang diatur dalam berbagai peraturan perundang-undangan dapat tercapai.

d. Penanam Modal Bertanggung Jawab Menciptakan Keselamatan, Kesehatan, Kenyamanan, dan Kesejahteraan Pekerja ${ }^{60}$

Untuk menganalisa hak dan kewajiban investor asing serta pekerja Indonesia dalam konteks tanggung jawab investor, penelitian ini mencoba mengupas satu per satu aspek yang diminta oleh UU Penanaman Modal dimulai dari keselamatan, kesehatan, kenyamanan, serta kesejahteraan pekerja. Hak dan kewajiban ini tidak terbatas oleh UU Penanaman Modal saja, tetapi juga peraturan perundang-undangan lain yang mengatur hubungan antara investor asing dan pekerja Indonesia.

\section{1) Keselamatan Pekerja}

Peningkatan keselamatan serta kesehatan kerja (K3) adalah salah satu bagian tak terpisahkan dari peningkatan kondisi kerja. K3 bukan hanya ditujukan untuk kesejahteraan pekerja, tetapi juga bagi perkembangan produktivitas perusahaan. Pekerja yang mendapatkan pelayanan K3 dengan baik cenderung lebih termotivasi dalam bekerja sehingga mampu menghasilkan kualitas barang dan jasa yang lebih baik dalam proses produksi. ${ }^{61}$

Keselamatan pekerja merupakan salah satu kewajiban yang

Pasal 14 Undang-Undang Nomor 13 Tahun 2003 tentang Ketenagakerjaan (Lembaran Negara Republik Indonesia Tahun 2003 Nomor 39 , Tambahan Lembaran Negara Republik Indonesia Nomor 4279).

57 E. Mansfield, "East-West Technological Transfer Issues and Problems, International Technology Transfer: Forms, Resource Requirements and Policies", American Economic Review, Vol. 65, No. 2, 1975, hlm. 372-276.

$58 \quad$ Ibid.

59 Pasal 26 ayat (3) Peraturan Menteri Tenaga Kerja dan Transmigrasi Nomor 12 Tahun 2013 tentang Tata Cara Penggunaan Tenaga Kerja Asing.

60 Pasal 16 huruf e Undang-Undang Nomor 25 Tahun 2007 tentang Penanaman Modal (Lembaran Negara Republik Indonesia Tahun 2007 Nomor 67, Tambahan Lembaran Negara Republik Indonesia Nomor 4724).

${ }_{61}$ Benjamin O. Alli, 2008, Fundamental Principles of Occupational Health and Safety, International Labour Office, Geneva, hlm. 27. 
harus dipenuhi oleh investor asing sebagai pemberi kerja. Setiap tenaga kerja, yang bekerja pada pengusaha, baik perusahaan penanam modal asing maupun dalam negeri, berhak mendapatkan perlindungan keselamatan demi kesejahteraan hidup dan meningkatkan produksi serta produktivitas nasional. ${ }^{62}$ Aturan yang mendasari keselamatan kerja terdapat pada Undang-Undang Nomor 1 Tahun 1970 tentang Keselamatan Kerja. Pada undang-undang ini, disebutkan bahwa keselamatan kerja yang dimaksud meliputi segala jenis tempat kerja; darat, tanah, permukaan air, dalam air, maupun udara dalam wilayah hukum NKRI. ${ }^{63}$

UU Keselamatan Kerja menentukan adanya pegawai pengawas kerja (pengawas) yang memiliki keahlian khusus untuk mengawasi secara langsung penerapan keselamatan kerja di lapangan. ${ }^{64}$ Dalam tugasnya, pengawas bersinergi dengan ahli keselamatan kerja.

Kedua jabatan tersebut ditunjuk oleh Menteri Tenaga Kerja, hanya saja pengawas merupakan bagian dari Departemen Tenaga Kerja dan
Transmigrasi. ${ }^{65}$ Sementara itu, ahli keselamatan kerja berasal dari luar departemen. ${ }^{66}$

Selain itu, UU Keselamatan Kerja juga mensyaratkan adanya pengurus yang merupakan pemimpin langsung suatu tempat kerja atau bagiannya yang berdiri sendiri. ${ }^{67}$ Keberadaan pengurus menjadi tanggung jawab pengusaha, dalam hal ini investor asing. Adapun pengurus diwajibkan untuk memastikan kesehatan para pekerja ${ }^{68}$ serta memeriksakan pekerja secara berkala pada dokter yang telah ditunjuk oleh perusahaan. ${ }^{69}$ Perlindungan terhadap keselamatan dan kesehatan pekerja merupakan salah satu bentuk hak dasar pekerja. $^{70}$ Untuk menjamin keselamatan pekerja, para pekerja memiliki kewajiban untuk memelihara keselamatannya masing-masing, ${ }^{71}$ serta keselamatan orang lain yang memiliki risiko terkena dampak dari tindakan atau kegagalan para pekerja. Untuk menciptakan keselamatan di tempat kerja, para pekerja hendaknya memiliki pengetahuan yang memadai terhadap bidang kerja yang akan mereka lakukan. ${ }^{72}$ Pekerja juga diberi

62 Pertimbangan huruf a Undang-Undang Nomor 1 Tahun 1970 tentang Keselamatan Kerja (Lembaran Negara Republik Indonesia Tahun 1970 Nomor 1, Tambahan Lembaran Negara Republik Indonesia Nomor 2918).

63 Pasal 2 ayat (1) Undang-Undang Nomor 1 Tahun 1970 tentang Keselamatan Kerja (Lembaran Negara Republik Indonesia Tahun 1970 Nomor 1, Tambahan Lembaran Negara Republik Indonesia Nomor 2918).

64 Pasal 1 ayat (7) Undang-Undang Nomor 1 Tahun 1970 tentang Keselamatan Kerja (Lembaran Negara Republik Indonesia Tahun 1970 Nomor 1, Tambahan Lembaran Negara Republik Indonesia Nomor 2918).

65 Pasal 1 ayat (6) Undang-Undang Nomor 1 Tahun 1970 tentang Keselamatan Kerja (Lembaran Negara Republik Indonesia Tahun 1970 Nomor 1, Tambahan Lembaran Negara Republik Indonesia Nomor 2918).

66 Pasal 1 ayat (7) Undang-Undang Nomor 1 Tahun 1970 tentang Keselamatan Kerja (Lembaran Negara Republik Indonesia Tahun 1970 Nomor 1, Tambahan Lembaran Negara Republik Indonesia Nomor 2918).

67 Pasal 1 ayat (3) Undang-Undang Nomor 1 Tahun 1970 tentang Keselamatan Kerja (Lembaran Negara Republik Indonesia Tahun 1970 Nomor 1, Tambahan Lembaran Negara Republik Indonesia Nomor 2918).

68 Pasal 8 ayat (1) Undang-Undang Nomor 1 Tahun 1970 tentang Keselamatan Kerja (Lembaran Negara Republik Indonesia Tahun 1970 Nomor 1, Tambahan Lembaran Negara Republik Indonesia Nomor 2918).

69 Pasal 8 ayat (2) Undang-Undang Nomor 1 Tahun 1970 tentang Keselamatan Kerja (Lembaran Negara Republik Indonesia Tahun 1970 Nomor 1, Tambahan Lembaran Negara Republik Indonesia Nomor 2918).

70 Pasal 7 The United Nations International Covenant on Economic, Social, and Cultural Rights 1976.

71 Pasal 13 Undang-Undang Nomor 1 Tahun 1970 tentang Keselamatan Kerja (Lembaran Negara Republik Indonesia Tahun 1970 Nomor 1, Tambahan Lembaran Negara Republik Indonesia Nomor 2918).

72 Menurut Pasal 9 ayat (2) Undang-Undang Nomor 1 Tahun 1970 tentang Keselamatan Kerja, pengurus hanya dapat mempekerjakan tenaga kerja setelah ia yakin bahwa tenaga kerja telah memahami syarat-syarat keamanan, perlindungan diri, serta cara dan sikap yang aman dalam melaksanakan pekerjaan. 
hak untuk menghentikan pekerjaannya apabila ada kemungkinan pekerjaan tersebut menimbulkan bahaya bagi keselamatan maupun kesehatan para pekerja. $^{73}$

Kesadaran para pekerja perlu ditingkatkan melalui pendidikan serta pelatihan yang memadai. Menurut UU Keselamatan kerja, pembinaan dan pelatihan terhadap pekerja merupakan kewajiban pengurus. Dalam perusahaan penanaman modal asing, pengurus ditunjuk langsung oleh perusahaan untuk memimpin langsung kegiatan di tempat kerja. ${ }^{74}$ Dalam pendidikan ini, para pekerja tidak hanya dibekali mengenai ilmu pengetahuan tentang bidang pekerjaan yang akan mereka lakukan, namun juga mengenai bahaya dan potensi kecelakaan kerja yang mungkin timbul. ${ }^{75}$ Dengan demikian, pekerja akan memiliki tingkat kesadaran untuk tidak melakukan serta menghindari hal-hal yang akan membahayakan diri mereka maupun orang lain.

Pembinaan tenaga kerja merupakan salah satu langkah preventif yang dapat dilakukan oleh pengurus. Pada tahap ini, pekerja dibekali dengan pemahaman serta pengetahuan yang memadai mengenai aspek keselamatan kerja serta langkah-langkah pencegahan risiko kecelakaan kerja. Namun, jika risiko tidak dapat ditanggulangi dan menimbulkan kecelakaan kerja, pekerja haruslah memiliki kemampuan untuk melakukan tindakan kuratif. Oleh karena itu, pembinaan bagi para pekerja juga meliputi pelatihan pemberian pertolongan pertama dalam kecelakaan kerja. $^{76}$

\section{2) Kesehatan Pekerja}

Kesehatan didefinisikan sebagai keadaan sehat, baik secara fisik, mental, spiritual, maupun sosial yang memungkinkan setiap orang untuk hidup produktif secara sosial dan ekonomis. ${ }^{77}$ Sementara itu, menurut Occupational Safety and Health Convention, kesehatan kerja bukan hanya berarti ketiadaan wabah atau penyakit, tetapi termasuk di dalamnya elemen fisik dan mental yang mempengaruhi kesehatan terkait dengan keselamatan dan kebersihan dalam tempat kerja. ${ }^{78}$ Secara umum, peningkatan kesehatan bertujuan untuk meningkatkan kesadaran, kemauan, dan kemampuan hidup sehat untuk meningkatkan derajat masyarakat sebagai investasi bagi pembangunan SDM yang produktif secara sosial dan ekonomis. ${ }^{79}$ Secara khusus, kesehatan kerja perlu diupayakan untuk melindungi pekerja dari gangguan kesehatan serta pengaruh buruk yang diakibatkan oleh pekerjaan. ${ }^{80}$ Dalam

Pasal 12 huruf e Undang-Undang Nomor 1 Tahun 1970 tentang Keselamatan Kerja (Lembaran Negara Republik Indonesia Tahun 1970 Nomor 1, Tambahan Lembaran Negara Republik Indonesia Nomor 2918).

74 Pasal 1 ayat (3) Undang-Undang Nomor 1 Tahun 1970 tentang Keselamatan Kerja (Lembaran Negara Republik Indonesia Tahun 1970 Nomor 1, Tambahan Lembaran Negara Republik Indonesia Nomor 2918).

75 Pasal 9 ayat (3) Undang-Undang Nomor 1 Tahun 1970 tentang Keselamatan Kerja (Lembaran Negara Republik Indonesia Tahun 1970 Nomor 1, Tambahan Lembaran Negara Republik Indonesia Nomor 2918).

76 Pasal 9 ayat (3) Undang-Undang Nomor 1 Tahun 1970 tentang Keselamatan Kerja (Lembaran Negara Republik Indonesia Tahun 1970 Nomor 1, Tambahan Lembaran Negara Republik Indonesia Nomor 2918).

77 Pasal 1 ayat (1) Undang-Undang Nomor 36 Tahun 2009 tentang Kesehatan (Lembaran Negara Republik Indonesia Tahun 2009 Nomor 144 Tambahan Lembaran Negara Republik Indonesia Nomor 5063).

78 Pasal 3 huruf e Occupational Safety and Health Convention 1981 International Labour Organization.

79 Pasal 3 Undang-Undang Nomor 36 Tahun 2009 tentang Kesehatan (Lembaran Negara Republik Indonesia Tahun 2009 Nomor 144, Tambahan Lembaran Negara Republik Indonesia Nomor 5063).

80 Pasal 164 ayat (1) Undang-Undang Nomor 36 Tahun 2009 tentang Kesehatan (Lembaran Negara Republik Indonesia Tahun 2009 Nomor 144, Tambahan Lembaran Negara Republik Indonesia Nomor 5063). 
penjabaran lebih lanjut, kesehatan kerja diatur dalam berbagai keputusan Menteri Kesehatan. Terdapat berbagai keputusan mengenai standar kesehatan dan keselamatan kerja yang diklasifikasikan berdasarkan tempat kerja.

Perwujudan kesehatan pekerja merupakan tanggung jawab utama perusahaan. Untuk mempermudah tugas di dalam internal perusahaan, UU Kesehatan membagi kewajiban kepada dua pihak, yaitu pengelola tempat kerja (pengurus) serta pengusaha, dalam hal ini perusahaan penanam modal. Pengelola tempat kerja diwajibkan untuk menaati standar kesehatan kerja $^{81}$ serta bertanggung jawab atas kecelakaan kerja yang terjadi di lingkungan kerja. ${ }^{82}$ Upaya kesehatan melalui pencegahan, peningkatan, pengobatan, serta pemulihan bagi tenaga kerja merupakan serangkaian kewajiban yang harus dilakukan oleh pengelola tempat kerja terhadap tenaga kerjanya. ${ }^{83}$

Agar kegiatan pencegahan, peningkatan, pengobatan, serta pemulihan kesehatan dapat dilakukan, maka perlu ada penjamin serta penanggung jawab dari keseluruhan upaya tersebut. Dalam UU Kesehatan, tanggung jawab ini diberikan kepada pengusaha. ${ }^{84}$ Pengusaha juga diberikan kewajiban untuk menanggung biaya atas gangguan kesehatan akibat kerja yang diderita oleh pekerja. ${ }^{85}$

Kesehatan pekerja merupakan faktor yang sangat penting bagi terciptanya produktivitas perusahaan yang optimal, sehingga jaminan kesehatan pekerja diberikan bukan semata-mata untuk memenuhi tujuan kemanusiaan dan kesejahteraan pekerja, tetapi juga untuk menjamin keberlangsungan proses produksi dilihat dari segi ekonomi. Selain kewajiban yang harus dilakukan oleh perusahaan penanam modal asing (investor asing), pekerja Indonesia juga memiliki kewajiban untuk serta bertanggung jawab atas pemeliharaan kesehatannya di lingkungan kerja. Para pekerja wajib menciptakan dan menjaga kesehatan tempat kerja yang sehat dan menaati peraturan yang berlaku di tempat kerja. $^{86}$

Peran pemerintah terletak pada pembentukan legislasi yang mampu mengatur terpenuhinya hak pekerja yang menjamin keselamatan dan kesehatannya. Salah satu wujud konkret dari peraturan perundang-undangan mengenai keselamatan dan kesehatan kerja dapat dilihat pada Peraturan Pemerintah Nomor 50 Tahun 2012 tentang Penerapan Sistem Manajemen Keselamatan dan Kesehatan Kerja (PP SMK3). Secara umum, PP SMK3 membagi kewajiban antara pengusaha dan pemerintah dalam mewujudkan

Pasal 164 ayat (6) Undang-Undang Nomor 36 Tahun 2009 tentang Kesehatan (Lembaran Negara Republik Indonesia Tahun 2009 Nomor 144 , Tambahan Lembaran Negara Republik Indonesia Nomor 5063).

82 Pasal 164 ayat (7) Undang-Undang Nomor 36 Tahun 2009 tentang Kesehatan (Lembaran Negara Republik Indonesia Tahun 2009 Nomor 144 , Tambahan Lembaran Negara Republik Indonesia Nomor 5063).

83 Pasal 165 ayat (1) Undang-Undang Nomor 36 Tahun 2009 tentang Kesehatan (Lembaran Negara Republik Indonesia Tahun 2009 Nomor 144 , Tambahan Lembaran Negara Republik Indonesia Nomor 5063).

84 Pasal 166 ayat (1) Undang-Undang Nomor 36 Tahun 2009 tentang Kesehatan (Lembaran Negara Republik Indonesia Tahun 2009 Nomor 144, Tambahan Lembaran Negara Republik Indonesia Nomor 5063).

85 Pasal 166 ayat (2) Undang-Undang Nomor 36 Tahun 2009 tentang Kesehatan (Lembaran Negara Republik Indonesia Tahun 2009 Nomor 144 , Tambahan Lembaran Negara Republik Indonesia Nomor 5063).

86 Pasal 165 ayat (2) Undang-Undang Nomor 36 Tahun 2009 tentang Kesehatan (Lembaran Negara Republik Indonesia Tahun 2009 Nomor 144 , Tambahan Lembaran Negara Republik Indonesia Nomor 5063). 
keselamatan dan kesehatan kerja. Pengusaha yang mempekerjakan paling sedikit seratus orang pekerja atau mempunyai tingkat potensi bahaya tinggi diwajibkan menerapkan SMK3 di perusahaannya. ${ }^{87}$ Kewajiban tersebut meliputi penetapan kebijakan $\mathrm{K} 3$, perencanaan $\mathrm{K} 3$, pelaksanaan rencana $\mathrm{K} 3$, pemantauan evaluasi kinerja K3, serta peninjauan dan peningkatan kinerja SMK3. ${ }^{88}$

Sementara pemerintah memiliki kewajiban untuk mengawasi pelaksanaan SMK3 pada tingkat pusat, provinsi, dan/atau kabupaten/ kota. Pengawasan ini dilakukan oleh pengawas ketenagakerjaan yang bertugas pada masing-masing tingkat. Hasil dari proses pengawasan terhadap perusahaan kemudian digunakan sebagai dasar untuk melakukan pembinaan. ${ }^{89}$ Pemerintah melalui Menteri Ketenagakerjaan dan Transmigrasi juga memiliki hak untuk menerima laporan penilaian perusahaan mengenai penerapan SMK3. ${ }^{90}$ Penilaian ini dilakukan oleh lembaga audit independen yang ditunjuk oleh Menteri atas permohonan perusahaan. ${ }^{91}$

\section{3) Kenyamanan Pekerja}

Perihal kenyamanan bagi pekerja belum didefinisikan dalam peraturan perundang-undangan di Indonesia. Meskipun UU Penanaman Modal meletakkan tanggung jawab kenyamanan kerja pada penanam modal, namun belum ada penjelasan lebih lanjut mengenai standar dan kondisi kenyamanan di lingkungan kerja. Dalam UU Ketenagakerjaan, pemberi kerja hanya diwajibkan untuk memberikan perlindungan yang mencakup kesejahteraan, keselamatan, serta kesehatan tenaga kerja. ${ }^{92}$

Meskipun pemeliharaan kenyamanan belum dijabarkan secara tertulis dalam hukum positif di Indonesia, tetapi perusahaan penanam modal memiliki tanggung jawab untuk memelihara kenyamanan bagi pekerjanya. Perusahaan penanaman modal asing dapat menentukan kebijakan kerja sendiri, atau jika memungkinkan, mengacu kepada standar kenyamanan yang ditetapkan oleh negara tempatnya berasal.

Peneliti berpendapat bahwa perusahaan penanaman modal asing hendaknya menetapkan standar kenyamanan bagi para pekerjanya. Selain untuk menjamin terpenuhinya hak-hak pekerja, hal ini juga ditujukan untuk menghindarkan perusahaan dari masalah yang akan dihadapi pada kemudian hari karena adanya perbedaan standar kenyamanan yang dituntut oleh pekerja. Oleh karena itu, penetapan standar kenyamanan hendaknya mempertimbangkan serta mengakomodasi saran dan pertimbangan dari wakil pekerja/serikat buruh di perusahaan yang bersangkutan. ${ }^{93}$

\footnotetext{
Pasal 5 ayat (2) Undang-Undang Nomor 36 Tahun 2009 tentang Kesehatan (Lembaran Negara Republik Indonesia Tahun 2009 Nomor 144, Tambahan Lembaran Negara Republik Indonesia Nomor 5063).

Pasal 6 ayat (1) Peraturan Pemerintah Nomor 50 Tahun 2012 tentang Penerapan Sistem Manajemen Keselamatan dan Kesehatan Kerja. Pasal 20 Peraturan Pemerintah Nomor 50 Tahun 2012 tentang Penerapan Sistem Manajemen Keselamatan dan Kesehatan Kerja. Pasal 17 ayat (1) Peraturan Pemerintah Nomor 50 Tahun 2012 tentang Penerapan Sistem Manajemen Keselamatan dan Kesehatan Kerja. Pasal 16 ayat (1) Peraturan Pemerintah Nomor 50 Tahun 2012 tentang Penerapan Sistem Manajemen Keselamatan dan Kesehatan Kerja. Pasal 35 ayat (3) Undang-Undang Nomor 13 Tahun 2003 tentang Ketenagakerjaan (Lembaran Negara Republik Indonesia Tahun 2003 Nomor 39, Tambahan Lembaran Negara Republik Indonesia Nomor 4279).

93 Usulan ini mengacu pada Pasal 110 ayat (1) dan (2) dimana pembentukan peraturan perusahaan haruslah memperhatikan saran dan pertimbangan dari wakil pekerja/buruh serta serikat pekerja/buruh.
} 


\section{4) Kesejahteraan Pekerja}

Kesejahteraan pekerja didefinisikan sebagai pemenuhan kebutuhan dan/atau keperluan yang bersifat jasmani dan rohani, baik di dalam maupun di luar hubungan kerja, yang secara langsung atau tidak langsung dapat mempertinggi produktivitas kerja dalam lingkungan kerja yang aman dan sehat. ${ }^{94}$ Dalam UU Ketenagakerjaan, ada tiga hak utama pekerja dalam rangka meningkatkan kesejahteraannya, yaitu jaminan sosial tenaga kerja, fasilitas kesejahteraan, serta koperasi pekerja. ${ }^{95}$

4. Ketidakseimbangan antara Investor Asing dan Pekerja Indonesia dari Segi Hukum sebagai Budaya Perilaku (Legal Culture)

Budaya hukum, bersama sama dengan sosiologi hukum, sejarah hukum, psikologi hukum, dan perbandingan hukum, merupakan bagian dari apa yang disebut sebagai disiplin hukum (legal theory). ${ }^{96}$ Dalam pembentukannya, hukum tidak terlepas dari kepentingan masyarakat. Dalam pembentukan peraturan perundangundangan tentang penanaman modal (asing), hukum juga memperhatikan kepentingan nasional serta kepentingan investor asing yang akan melakukan penanaman modal di Indonesia. Hal ini menunjukkan bahwa hukum sebagai norma sosial tidak semata-mata menentukan dirinya sendiri, tetapi juga dipengaruhi oleh masyarakat di mana hukum itu berada. ${ }^{97}$

Friedman menjabarkan bahwa dalam konteks analitik, budaya hukum dapat diartikan sebagai tindakan-tindakan yang biasa dilakukan dalam interaksi antara sistem hukum dan lingkungan sekitarnya. Sementara itu, dalam konteks deskriptif, budaya hukum diartikan sebagai sejumlah fenomena yang saling terkait; pengetahuan umum dan sikap masyarakat terhadap suatu sistem hukum, serta pola perilaku terhadap sistem hukum itu sendiri, termasuk penilaian terhadap keadilan, kemanfaatan, serta keabsahan hukum..$^{98}$

Budaya hukum merupakan salah satu komponen utama dari sistem hukum yang sangat berperan dalam pembentukan hukum di tengahtengah masyarakat. Dalam hubungan antara investor asing dengan pekerja Indonesia, peneliti menemukan beberapa hal yang menunjukkan adanya ketidakseimbangan dari segi budaya perilaku. Salah satunya terjadi ketika investor asing menganggap bahwa pekerja Indonesia merupakan salah satu faktor produksi yang sama dengan faktor produksi yang lainnya.

Faktor produksi adalah segala sesuatu yang disediakan oleh alam dan atau diciptakan sendiri oleh manusia sehingga dapat digunakan untuk menghasilkan barang ataupun jasa. ${ }^{99}$ Faktor produksi utama yang dibutuhkan oleh perusahaan dalam menghasilkan barang maupun jasa meliputi alam, modal, tenaga kerja, serta kewirausahaan. ${ }^{100}$ Faktor-faktor tersebutlah yang merupakan syarat utama yang harus diusahakan oleh perusahaan agar kegiatan produksinya berjalan dengan optimal.

Meskipun pekerja merupakan salah satu faktor produksi utama, investor asing hendaknya tidak melupakan bahwa pekerja juga merupakan individu yang memiliki hak dan kewajiban dalam sebuah hubungan kerja. Hak-hak pekerja yang diatur dalam undang-undang menjadi tanggung jawab serta kewajiban yang harus dipenuhi oleh investor

\footnotetext{
94 Pasal 1 angka 69 Keputusan Menteri Tenaga Kerja dan Transmigrasi Nomor KEP.250/MEN/XII/2008 tentang Klasifikasi dan Karakteristik dari Jenis Informasi Ketenagakerjaan.

95 Bagian Ketiga Undang-Undang Nomor 13 Tahun 2003 tentang Ketenagakerjaan (Lembaran Negara Republik Indonesia Tahun 2003 Nomor 39, Tambahan Lembaran Negara Republik Indonesia Nomor 4279).

96 Reiner S.D. Sitanala, "Kajian Filosofis terhadap Hukum sebagai Institusi Budaya dalam Masyarakat Indonesia yang Sedang Berkembang", Jurnal Sasi, Vol. 17, No. 4, Oktober-Desember 2011, hlm. 58-63. 
asing. Pemenuhan hak-hak tersebut ditujukan baik untuk meningkatkan kesejahteraan pekerja serta peningkatan kualitas sumber daya manusia yang ada dalam sebuah perusahaan.

Untuk menjamin terpenuhinya hakhak tenaga kerja, pemerintah berperan dalam membentuk peraturan perundang-undangan yang tidak memihak. Oleh karena itu, dalam UU Penanaman Modal, investor asing maupun perusahaan pengguna tenaga kerja asing memiliki kewajiban untuk meningkatkan kemampuan dan keahlian pekerja Indonesia melalui pelatihan serta alih teknologi. Pengetahuan dan pengalaman baru, digabungkan dengan kemampuan pekerja Indonesia yang tersedia, mampu menjadi aset apresiasi bagi perusahaan. ${ }^{101}$ Hal ini sungguh jauh berbeda dengan faktor produksi yang lain seperti mesin produksi yang memiliki nilai depresiasi dari waktu ke waktu. ${ }^{102}$

Budaya hukum yang tidak seimbang dalam hubungan antara investor asing dengan pekerja Indonesia menempatkan pemerintah sebagai jembatan penghubung antara kepentingan kedua belah pihak. Dalam situasi seperti ini, pemerintah diharapkanmampumenciptakansuatukeseimbangan melalui peraturan perundang-undangan. Salah satu cara yang telah ditempuh oleh pemerintah dalam rangka melindungi hak-hak pekerja adalah dengan menetapkan regulasi pengupahan yang mencakup upah minimum, kesepakatan upah, struktur skala upah, serta peninjauan upah secara berkala. ${ }^{103}$

Penetapan upah minimum ini ditujukan untuk melindungi upah pekerja agar tidak merosot pada tingkat yang paling rendah sebagai akibat dari ketidakseimbangan pasar kerja. Pemerintah menilai perlu adanya penyelarasan kebijakan upah minimum dengan memperhatikan produktivitas dan pertumbuhan ekonomi guna mewujudkan keberlangsungan usaha dan peningkatan kesejahteraan pekerja. ${ }^{104}$ Pengusahaan kesejahteraan bagi kaum pekerja tampak pada tujuan penetapan upah minimum, yaitu untuk memenuhi Kebutuhan Hidup Layak (KHL). ${ }^{105}$

Selain mekanisme penetapan upah minimum, pemerintah juga membuka kesempatan bagi pengusaha dan pekerja atau serikat pekerja/buruh untuk menetapkan sendiri upah berdasarkan kesepakatan. Kesepakatan yang dicapai antara kedua belah pihak tetap harus menaati peraturan perundang-undangan yang ada. Salah satunya adalah ketentuan mengenai besarnya kesepakatan upah yang tidak boleh lebih rendah dari ketentuan upah minimum. ${ }^{106}$

\section{Penyebab Ketidakseimbangan Hak dan Kewajiban antara Investor Asing dan Pekerja Indonesia dalam Peraturan Perundang-undangan Penanaman Modal}

Berdasarkan Pasal 10 UU Pembentukan

Peraturan Perundang-undangan, materi muatan yang harus diatur dalam undang-undang, salah satunya, meliputi pengaturan lebih lanjut mengenai ketentuan Undang-Undang Dasar Negara Republik Indonesia Tahun 1945. UUD 1945 Pasal 28D telah mengatur tentang hak setiap orang untuk bekerja serta mendapat imbalan dan perlakuan yang adil dan layak dalam hubungan kerja. ${ }^{107}$ Secara eksplisit, UUD telah menyatakan bahwa seseorang yang bekerja berhak mendapatkan imbalan. Selain itu, setiap orang yang bekerja juga berhak mendapatkan perlakuan yang adil dan layak dalam suatu hubungan kerja.

Menurut UU Ketenagakerjaan, hubungan

\footnotetext{
01 O. Zeynep Aksin, 2003, On Valuing Appreciating Human Assets in Services, Koc University, Istanbul, hlm. 3.

102 Ibid.

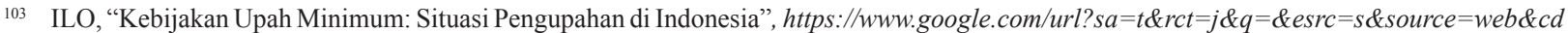

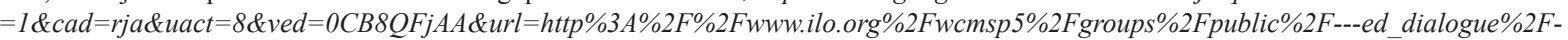
--actrav $\% 2$ Fdocuments $\% 2 F m e e t i n g d o c u m e n t \% 2 F w c m s ~ 210427 . p d f \& e i=54 A N V P i r G J O N u A S Z m Y K g A w \& u s g=A F Q j C N F c l 9 O-G 0 y b y w H t$ 9s5HazjzrnHNCw\&sig2 = kbbvBNiL02jjHcnYaSbK0g\&bvm=bv.74649129,d.c2E, diakses 20 Maret 2015.

104 Ibid.

105 Ibid.

106 Pasal 91 ayat (1) Undang-Undang Nomor 13 Tahun 2003 tentang Ketenagakerjaan (Lembaran Negara Republik Indonesia Tahun 2003 Nomor 39, Tambahan Lembaran Negara Republik Indonesia Nomor 4279).

107 Pasal 28D ayat (2) Undang-Undang Dasar Negara Republik Indonesia Tahun 1945.
} 
kerja adalah hubungan antara pengusaha dengan pekerja/buruh berdasarkan perjanjian kerja yang mempunyai unsur pekerjaan, upah, dan perintah. ${ }^{108}$ Hubungan antara pemberi kerja dengan pekerja merupakan suatu hubungan yang tidak seimbang. Pemberi kerja, sebagai pemilik modal, memiliki posisi tawar yang lebih tinggi dibandingkan dengan pekerja. Oleh karena itu, pemerintah ikut berperan dalam hubungan industrial yang terbentuk antara pengusaha, pekerja, serta pemerintah. ${ }^{109}$ Oleh karena itu, perlakuan yang adil dan layak kepada pekerja bukan hanya merupakan kewajiban pengusaha, tetapi juga pemerintah.

Peran pemerintah dalam mewujudkan perlakuan yang adil dan layak kepada para pekerja lebih ditekankan pada keberadaan peraturan perundang-undangan yang menjamin terpenuhinya hak dasar pekerja untuk mewujudkan kesejahteraan. Peraturan inilah yang harus dijalankan oleh pemberi kerja, dalam hal ini perusahaan penanam modal asing, agar kesejahteraan pekerja Indonesia tetap terjamin. Untuk mengetahui hak pekerja yang dijamin oleh pemerintah, penulis memaparkan hak-hak tersebut berdasarkan peraturan perundangundangan mengenai ketenagakerjaan. Berdasarkan UU Ketenagakerjaan sendiri, berikut merupakan hak-hak pekerja yang harus didapatkan:

\section{a. Hak Memperoleh Perlakuan yang Sama Tanpa Diskriminasi ${ }^{110}$}

Diskriminasi berlaku secara horizontal, yakni bahwa pengusaha harus memberikan hak dan kewajiban pekerja/buruh tanpa membedakan jenis kelamin, suku, ras, agama, warna kulit, dan aliran politik. ${ }^{11}$

\section{b. Hak Memperoleh Pelatihan Kerja dan Pengakuan Kompetensi Kerja ${ }^{112}$}

Menurut UU Ketenagakerjaan, pengembangan kompetensi kerja dapat dilakukan baik melalui pelatihan kerja maupun pemagangan. Pekerja yang telah mengikuti pengembangan kompetensi kerja kemudian berhak mendapatkan pengakuan kompetensi kerja atau sertifikasi. Kewajiban untuk menyelenggarakan pelatihan kerja juga dicantumkan di dalam UU Penanaman Modal. Hal ini menunjukkan bahwa pemerintah menaruh perhatian yang cukup besar dalam meningkatkan kualitas sumber daya manusia, terutama para pekerja di Indonesia.

\section{c. Hak Mendapatkan Perlindungan \\ Pasal 86 UU Ketenagakerjaan} mengatur bahwa pekerja berhak memperoleh perlindungan atas keselamatan dan kesehatan kerja, moral dan kesusilaan, serta perlakuan yang sesuai dengan harkat dan martabat manusia serta nilai-nilai agama. ${ }^{113}$ Untuk memenuhi hak pekerja tersebut, ada upaya keselamatan dan kesehatan kerja yang diatur dalam UU Keselamatan Kerja serta UU Kesehatan.

\section{d. Hak Atas Pengupahan}

Tujuan pemberian upah yang tercantum dalam peraturan perundangundangan terkait Ketenagakerjaan adalah untuk memenuhi penghidupan yang layak serta melindungi pekerja. Penulis berpendapat bahwa pengaturan serta tujuan pemberian upah telah sesuai dengan tujuan

108 Pasal 1 angka 15 Undang-Undang Nomor 13 Tahun 2003 tentang Ketenagakerjaan (Lembaran Negara Republik Indonesia Tahun 2003 Nomor 39, Tambahan Lembaran Negara Republik Indonesia Nomor 4279).

109 Pasal 1 angka 16 Undang-Undang Nomor 13 Tahun 2003 tentang Ketenagakerjaan (Lembaran Negara Republik Indonesia Tahun 2003 Nomor 39, Tambahan Lembaran Negara Republik Indonesia Nomor 4279).

110 Pasal 6 Undang-Undang Nomor 13 Tahun 2003 tentang Ketenagakerjaan (Lembaran Negara Republik Indonesia Tahun 2003 Nomor 39 , Tambahan Lembaran Negara Republik Indonesia Nomor 4279).

111 Penjelasan Pasal 6 Undang-Undang Nomor 13 Tahun 2003 tentang Ketenagakerjaan (Lembaran Negara Republik Indonesia Tahun 2003 Nomor 39, Tambahan Lembaran Negara Republik Indonesia Nomor 4279).

112 Pasal 11 dan Pasal 12 Undang-Undang Nomor 13 Tahun 2003 tentang Ketenagakerjaan (Lembaran Negara Republik Indonesia Tahun 2003 Nomor 39, Tambahan Lembaran Negara Republik Indonesia Nomor 4279).

113 Pasal 86 ayat (1) Undang-Undang Nomor 13 Tahun 2003 tentang Ketenagakerjaan (Lembaran Negara Republik Indonesia Tahun 2003 Nomor 39, Tambahan Lembaran Negara Republik Indonesia Nomor 4279). 
bangsa untuk menciptakan kesejahteraan bagi warga negaranya.

\section{e. Hak Atas Jaminan Sosial}

Keberadaan BPJS Ketenagakerjaan merupakan salah satu perwujudan dari sistem jaminan sosial nasional yang ditujukan untuk memberikan kepastian perlindungan dan kesejahteraan sosial bagi seluruh rakyat. ${ }^{114}$ Hak atas jaminan sosial juga diatur oleh Pasal 28H UUD 1945 yang bertujuan untuk memungkinkan pengembangan diri secara utuh sebagai manusia yang bermartabat.

\section{Instrumen Perbaikan Kesejahteraan Hidup Buruh}

Secara umum, instrumen perbaikan kesejahteraan hidup buruh dapat dikategorikan menjadi dua bagian, yaitu instrumen upah dan instrumen non-upah. Instrumen upah hanya memiliki satu bagian, upah itu sendiri. Sementara instrumen non-upah dapat dikategorikan lagi menjadi: (a) pangan; (b) layanan kesehatan; (c) sandang dan perumahan; (d) pendidikan usaha dan kerja. ${ }^{115}$ Fokus peningkatan kesejahteraan buruh dalam peraturan perundang-undangan mengenai ketenagakerjaan lebih dititikberatkan pada instrumen upah. Peraturan Menteri Tenaga Kerja dan Transmigrasi Nomor 13 Tahun 2012 tentang Komponen Pelaksanaan Tahapan Pencapaian Kebutuhan Hidup Layak, misalnya, mendefinisikan kebutuhan hidup layak sebatas standar kebutuhan pekerja untuk dapat hidup layak secara fisik untuk kebutuhan satu bulan. ${ }^{116}$ Peraturan ini lebih lanjut menyuratkan bahwa parameter kebutuhan hidup yang layak hanya semata-mata bertumpu pada upah minimum bagi pekerja.

Beberapa instrumen non-upah yang lain, seperti layanan kesehatan, serta pendidikan dan usaha kerja telah juga diatur dalam UU
Ketenagakerjaan, tetapi lebih ditujukan untuk memberikan keuntungan kepada perusahaan penanam modal asing. Selain layanan kesehatan dan pendidikan kerja yang sifatnya wajib menurut peraturan perundang-undangan, ada pula fasilitas kesejahteraan yang sifatnya tidak memaksa bagi perusahaan. Kebutuhan dasar buruh berupa tempat tinggal termasuk dalam fasilitas kesejahteraan yang dapat diberikan oleh perusahaan penanam modal asing. Tetapi hal ini bersifat opsional, disesuaikan dengan kemampuan perusahaan itu sendiri.

Instrumen non-upah berupa pendidikan sangat dibutuhkan untuk meningkatkan kualitas sumber daya manusia. Pendidikan yang dimaksud mencakup sektor yang sangat luas, dan tidak hanya terbatas pada pelatihan kerja bagi pekerja yang berusaha pada perusahaan penanaman modal asing. Pendidikan untuk meningkatkan kualitas sumber daya manusia hendaknya diberikan mulai dari tingkat dasar. Sebagai contoh, Pemerintah Kota Surabaya telah berusaha meningkatkan pendidikan dengan cara meningkatkan dana alokasi pendidikan dalam APBD menjadi sekitar 32\%. Anggaran ini digunakan untuk kegiatan sekolah serta peningkatan kualitas SDM berbentuk pelatihan pemberdayaan ekonomi bagi warga Surabaya. ${ }^{117}$

\section{Kecenderungan Pemerintah}

Menurut Pasal 28D UUD 1945, setiap orang berhak mendapatkan perlakuan yang adil dan layak dalam hubungan kerja. Spirit pengaturan yang terdapat dalam konstitusi ini tampaknya belum diwujudkan dalam peraturan perundangundangan terkait. Dalam peraturan perundangundangan terkait ketenagakerjaan, hak pekerja yang diatur dalam UU terkait bukannya ditujukan untuk meningkatkan kesejahteraan tetapi justru untuk memberikan keuntungan kepada perusahaan penanam modal asing sebagai pemberi kerja.

114 Pertimbangan huruf (a) Undang-Undang Nomor 24 Tahun 2011 tentang Badan Penyelenggara Jaminan Nasional (Lembaran Negara Republik Indonesia Tahun 2011 Nomor 116, Tambahan Lembaran Negara Republik Indonesia Nomor 5256).

115 Boedi Rheza, "Instrumen Non-Upah sebagai Jalan Lain Peningkatan Kesejahteraan Buruh: Potret Lemahnya Komitmen Kebijakan Pemda", KPPOD Brief, Maret-April 2013.

116 Pasal 1 ayat (1) Peraturan Menteri Tenaga Kerja dan Transmigrasi Nomor 13 Tahun 2012 tentang Komponen dan Pelaksanaan Tahapan Pencapaian Kebutuhan Hidup Layak.

117 Achmad Faizal, "Fokus Soal SDM, Risma Alokasikan 32 Persen Anggaran untuk Pendidikan", http://tekno.kompas.com/read/2014/03/ 11/0403102/fokus.soal.sdm.risma.alokasikan.32.persen.anggaran.untuk.pendidikan, diakses 23 November 2014. 
Peraturan perundang-undangan mengenai ketenagakerjaan dan penanaman modal secara tidak langsung berusaha untuk menciptakan social dumping. Praktik ini biasa dilakukan oleh negara berkembang untuk meningkatkan competitive edge dengan negara berkembang yang lain. Social dumping ini banyak dilakukan dengan cara menekan upah minimum serta melalui kebijakan-kebijakan yang lebih menguntungkan penanam modal asing dengan tujuan agar Indonesia dilirik oleh investor asing untuk menanamkan modalnya.

Dalam peraturan perundang-undangan terkait Ketenagakerjaan pun, pemerintah cenderung membuat peraturan yang bertujuan untuk menarik investor asing ke Indonesia. Hal ini disebabkan karena Indonesia, sebagai negara berkembang, membutuhkan banyak suntikan dana untuk memperoleh modal dalam rangka pembangunan nasional. Namun demikian, kondisi negara berkembang seharusnya tidak dijadikan alasan yang permisif untuk tidak melindungi kepentingan serta kesejahteraan pekerja Indonesia.

\section{Kesimpulan}

Berdasarkan hasil penelitian ini, dapat disimpulkan bahwa: Pertama, ketidakseimbangan antara investor asing dengan pekerja Indonesia dalam peraturan perundang-undangan mengenai Penanaman Modal tampak dalam: (1) upah minimum yang sama terhadap pekerja Indonesia baik yang bekerja di PMA maupun PMDN; (2) hak dan kewajiban; serta (3) budaya hukum yang menganggap pekerja Indonesia sebagai salah satu faktor produksi yang sama halnya dengan faktor produksi yang lain. Kedua, ada 3 (tiga) penyebab yang mengakibatkan ketidakseimbangan pengaturan antara investor asing dan pekerja Indonesia, yaitu: (1) belum terpenuhinya komponen non-upah dalam instrumen perbaikan kesejahteraan hidup buruh; (2) social dumping yang menyebabkan kebijakan pemerintah cenderung berpihak kepada investor asing; serta (3) posisi tawar pekerja Indonesia yang rendah terhadap penanam modal asing. Saran yang dapat disampaikan kepada pemerintah melalui fungsi pembuatan peraturan perundangundangan yaitu agar pemerintah mampu berperan untuk menciptakan keadilan dan kesejahteraan bagi para pekerja Indonesia yang mencakup: Pertama, peningkatan kesehatan, keselamatan, kenyamanan, serta kesejahteraan dalam bekerja; dan Kedua, peningkatan kualitas Sumber Daya Manusia melalui pendidikan baik formal maupun non-formal

\section{DAFTAR PUSTAKA}

\section{A. Buku}

Aksin, O. Zeynep, 2003, On Valuing Appreciating Human Assets in Services, Koc University, Istanbul.

Alli, Benjamin O., 2008, Fundamental Principles of Occupational Health and Safety, International Labour Office, Geneva.

Budiono, Herlien, 2006, Asas Keseimbangan bagi Hukum Perjanjian Indonesia, Hukum Perjanjian Berlandaskan Asas-Asas Wigati Indonesia, Citra Aditya Bakti, Bandung.

Soekanto, Soerjono, 1986, Pengantar Penelitian Hukum, UI Press, Jakarta.

Sukirno, Sadono, 2009, Mikro Ekonomi: Teori Pengantar, Raja Grafindo Persada, Jakarta.
Sumardjono, Maria S.W., 2001, Pedoman Pembuatan Usulan Penelitian: Sebuah Panduan Dasar, Gramedia Pustaka Utama, Jakarta.

Suparji, 2008, Penanaman Modal Asing di Indonesia: Insentif v. Pembatasan, Universitas AlAzhar Indonesia Fakultas Hukum, Jakarta.

Roe, Mark J., 2001, The Shareholder Wealth Maximization Norm and Industrial Organization, Harvard Law School John M. Olin Center for Law, Economics and Business Discussion Paper Series, Cambridge.

\section{B. Artikel Jurnal}

Dawam, Rahardjo M., "Peranan Pekerja dalam Pembangunan Ekonomi”, Jurnal Reformasi 
Ekonomi, Vol. 4, No. 1, Januari-Desember 2003.

Hernawan, Ari, "Hubungan Industrial dalam Perspektif Teori Keadilan John Rawls", Jurnal Mimbar Hukum, Vol. 26, No. 2, Juni 2014.

Mansfield, E., "East-West Technological Transfer Issues and Problems, International Technology Transfer: Forms, Resource Requirements and Policies", American Economic Review, Vol. 65, No. 2.

Martin, Will, Keith E. Maskus, "Core Labour Standards and Competitiveness: Implications for Global Trade Policy", Review of International Economics, 2001.

Sitanala, Reiner S.D., "Kajian Filosofis terhadap Hukum sebagai Institusi Budaya dalam Masyarakat Indonesia yang sedang Berkembang", Jurnal Sasi, Vol. 17, No. 4, Oktober-Desember 2011.

\section{Makalah}

Kayakawa, Kimura, \& Lee, "How Does Country Risk Mather for Direct Investment?", Makalah, dipresentasikan dalam Economic Research Institute for ASEAN and East Asia (ERIA), Jakarta, 2012.

\section{Sumber Internet}

ASEAN Briefing, "Minimum Wage Levels Across ASEAN", http://www.aseanbriefing.com/ news/2013/04/16/minimum-wage-levelsacross-asean.html, diakses 31 Agustus 2014.

Badan Pusat Statistik, "Sensus Penduduk Tahun 2010", http://www.bps.go.id/tab_sub/view. php?tabel=1\&id_subyek $=12, \quad$ diakses 31 Agustus 2014.

, "Jumlah Angkatan Kerja, Penduduk Bekerja, Pengangguran, TPAK dan TPT", http://www.bps.go.id/tab_sub/ view.php? kat $=1 \&$ tabel $=1 \&$ daftar $=1 \& i d$ subyek $=06 \&$ notab $=5$, diakses 31 Agustus 2014.
Business Line, "Reform Labour Laws for FDI", http://www.hindu.com/businessline/2001/ 08/11/stories/01112003.htm, diakses 20 Maret 2015.

Ernawati, Dian, "Buruh Kerjanya Demo Terus, Investor Kabur!", http://suarapengusaha. om/2013/01/13/buruh-kerjanya-demo-terusinvestor-kabur/, diakses 15 Maret 2015.

Faizal, Achmad, "Fokus Soal SDM, Risma Alokasikan 32 Persen Anggaran untuk Pendidikan", http://tekno.kompas.com/read/ 2014/03/11/0403102/fokus.soal.sdm.risma. alokasikan.32.persen.anggaran.untuk. pendidikan, diakses 23 November 2014.

Galuh, Iwan, "Pengusaha Menilai Buruh Sulit Diajak Dialog", http://suarapengusaha. com/2013/01/21/pengusaha-menilai-buruhsulit-diajak-dialog/, diakses 15 Maret 2015.

ILO, "Kebijakan Upah Minimum: Situasi Pengupahan di Indonesia", https://www. google.com/url? sa $=t \& r c t=j \& q=\&$ esrc $=s$ $\&$ source $=$ web \&cd $=1 \&$ cad $=r j a \& u a c t=8 \&$ ved $=0 C B 8 Q F j A A \& u r l=h t t p \% 3 A \% 2 F \% 2 F$ www.ilo.org\% $\%$ Fwcmsp $5 \% 2$ Fgroups $\% 2 F p$ ublic $\% 2 F---e d$ dialogue $\% 2 F--$ actrav $\% 2$ Fdocuments\%2Fmeetingdocument $\% 2 F w c$ ms_210427.pdf\&ei=54ANVPirGJONuASZm $Y K g A w \& u s g=A F Q j C N F c l 9 O-G 0 y b y w H t 9_{s} 5$ HazjzrnHNCw\&sig2 $=k b b v B N i L 02 j j H c n Y a S$ $b K 0 g \& b v m=b v .74649129, d . c 2 E$, diakses 20 Maret 2015.

R., Lucky, "Buruh Sepati Indonesia Punya Upah Lebih Besar Dibandingkan China dan Vietnam", http://www.antaranews.com/berita/340950/buruh-sepatu-indonesa-punyaupah-lebih-besar-dibandingkan-china-danvietnam, diakses 15 Maret 2015.

Rheza, Boedi, "Instrumen Non-Upah sebagai Jalan Lain Peningkatan Kesejahteraan Buruh: Potret Lemahnya Komitmen Kebijakan Pemda”, KPPOD Brief, Maret-April 2013.

Yusuf, Hari, "Buruh Batam Serukan Boikot Produk Samsung", http://suarapengusaha. com/2012/12/10/buruh-batam-serukan- 
boikot-produk-samsung/, diakses 15 Maret 2015.

\section{Media Cetak/Surat Kabar}

Castle, James, "Hengkangnya Investor Asing dari Indonesia", Kompas, 29 November 2013.

Ahmad Erani Yustika, "Investasi dan Penanaman Modal”, Bisnis Indonesia, 24 September 2008.

\section{E. Peraturan Perundang-Undangan}

Undang-Undang Dasar Negara Republik Indonesia Tahun 1945.

Undang-Undang Nomor 1 Tahun 1970 tentang Keselamatan Kerja (Lembaran Negara Republik Indonesia Tahun 1970 Nomor 1, Tambahan Lembaran Negara Republik Indonesia Nomor 2918).

Undang-Undang Nomor 13 Tahun 2003 tentang Ketenagakerjaan (Lembaran Negara Republik Indonesia Tahun 2003 Nomor 39, Tambahan Lembaran Negara Republik Indonesia Nomor 4279).

Undang-Undang Nomor 25 Tahun 2007 tentang Penanaman Modal (Lembaran Negara Republik Indonesia Tahun 2007 Nomor 67, Tambahan Lembaran Negara Republik Indonesia Nomor 4724).
Undang-Undang Nomor 36 Tahun 2009 tentang Kesehatan (Lembaran Negara Republik Indonesia Tahun 2009 Nomor 144, Tambahan Lembaran Negara Republik Indonesia Nomor 5063).

Peraturan Pemerintah Nomor 50 Tahun 2012 tentang Penerapan Sistem Manajemen Keselamatan dan Kesehatan Kerja.

Peraturan Presiden Nomor 72 Tahun 2014 tentang Penggunaan Tenaga Kerja Asing serta Pelaksanaan Pendidikan dan Pelatihan Tenaga Kerja Pendamping.

Peraturan Menteri Tenaga Kerja dan Transmigrasi Nomor 12 Tahun 2013 tentang Tata Cara Penggunaan Tenaga Kerja Asing.

Peraturan Kepala Badan Koordinasi Penanaman Modal Nomor 3 Tahun 2012 tentang Pedoman dan Tata Cara Pengendalian Pelaksanaan Penanaman Modal.

Keputusan Menteri Tenaga Kerja dan Transmigrasi Nomor KEP.250/MEN/XII/2008 tentang Klasifikasi dan Karakteristik dari Jenis Informasi Ketenagakerjaan.

\section{F. Konvensi}

The United Nations International Covenant on Economic, Social, and Cultural Rights 1976. Occupational Safety and Health Convention 1981 International Labour Organization. 